\title{
Demans Tanısı Alan ve Almayan Geriatrik Bireylerin Beslenme Durumlarının Değerlendirilmesi
}

\section{Evaluation of the Nutritional Status of Geriatric Individuals with and without Dementia}

\author{
Gülçin Yllmaz ${ }^{1}$, Kezban Esen Karaca ${ }^{2}$
}

\begin{abstract}
Introduction: It was aimed to compare the malnutrition and nutritional status of geriatric individuals with and without dementia diagnosis, to evaluate the hand grip strength of geriatric individuals and to examine the difference between individuals who were diagnosed with dementia and those who were not diagnosed with dementia. Method: This study was carried out to compare the nutritional status of individuals who applied to Kastamonu State Hospital Neurology Outpatient Clinic, who were diagnosed with dementia and those who did not. The sample of the study consisted of 51 geriatric individuals aged 65 years and over who were diagnosed with dementia and 51 were not diagnosed with dementia. Groups were determined by randomized method. Anthropometric measurements and food consumption records of the participants were taken. Nutrition Risk Screening (NSI), Katz Activities of Daily Living Scale (ADL), Lawton\&Brody Instrumental Activities of Daily Living Scale (EGYA) and EAT-26 Eating Behavior Scale were applied. Results: 58.8\% $(\mathrm{n}=30)$ of individuals diagnosed with dementia are female, $41.2 \%(\mathrm{n}=21)$ are male, and $70.5 \%(\mathrm{n}=36)$ of individuals who are not diagnosed with dementia are female and $29.5 \%(\mathrm{n}=15)$ are male. The average age of individuals diagnosed with dementia was $78.84 \pm 7.844$ years, and the average age of individuals not diagnosed with dementia was $75.02 \pm 72.26$ years. It was determined that there is a significant difference between dementia and malnutrition $(p=0.001)$, and malnutrition increases as dementia increases. The mean scores of ADL and EGFA scales of individuals diagnosed with dementia $(4.039 \pm 1.469,2.118$ \pm 2.414 , respectively) were lower than those who were not diagnosed with dementia $(5.431 \pm 0.922,5.000 \pm 2.569$, respectively). There was no statistically significant difference between hand grip strength and dementia $(p>0.05)$. Conclusion: One of the important and over looked complications of dementia, the number of which is increasing in our country and around the world, is malnutrition. Nutritional status of individuals diagnosed with dementia should be evaluated regularly at the first meeting and in the follow-up of the disease. Adequate and balanced nutrition of the patient should be provided to prevent malnutrition and maintain functional independence. Further studies to examine the effects of nutrition on dementia will benefit medical nutrition therapy
\end{abstract}

Key words: Nutritional status, dementia, geriatrics, elderly, nutrition

\section{ÖZET}

Giriş: Demans tanısı alan ve almayan geriatrik bireylerin malnütrisyon ve beslenme durumlarını değerlendirmek, geriatrik bireylerin el kavrama gücü değerlendirilip demans tanısı alan ve almayan bireyler arasındaki farkı belirlemek amaçlanmıştır. Yöntem: Bu çalışma, Kastamonu Devlet Hastanesi Nöroloji Polikliniğine başvuran, demans tanısı alan ve almayan bireylerin beslenme durumlarını karşılaştırmak amacıyla yapılmıştır. Çalışmanın örneklemini 65 yaş ve üzeri 51 demans tanısı alan ve 51 demans tanısı almayan geriatrik birey oluşturmaktadır. Gruplar randomize yöntemle belirlenmiştir. Katılımcıların, antropometrik ölçümleri ve besin tüketim kayıtları alınmıştır. Beslenme Risk Taraması (NSI), Katz Günlük Yaşam Aktiviteleri Ölçeği (GYA), Lawton\&BrodyEnstrümental Günlük Yaşam Aktiviteleri Ölçeği (EGYA) ve EAT-26 Yeme Davranışı Ölçeği uygulanmıştır. Bulgular: Demans tanısı alan bireylerin \%58,8'si (n=30) kadın, \%41,2'si $(n=21)$ erkek, demans tanısı almayan bireylerin ise \%70,5'i $(n=36)$ kadın, \%29,5'i $(n=15)$ erkektir. Demans tanısı alan bireylerin yaş ortalaması 78,84 $\pm 7,84$ yıl, demans tanıs almayan bireylerin yaş ortalaması 75,02 $\pm 72,26$ yıl olarak saptanmıştır. Demans ile malnütrisyon arasında anlamlı bir farklılık olduğu(p=0,001), demans arttıkça malnütrisyonun arttığ belirlenmiştir. Demans tanısı alan bireylerin GYA ve EGYA ölçek puanlarının ortalaması (sırasıyla; 4,04 $\pm 1,47,2,12 \pm 2,41$ ) demans tanısı almayan bireylerden (sırasıyla; $5,43 \pm 0,92,5,00 \pm 2.57$ ) daha düşüktür. El kavrama gücü ve demans arasında istatistiksel olarak anlamlı bir fark bulunmamıştır ( $>0,05)$. Sonuç: Ülkemizde ve dünyada sayısı giderek artmakta olan demans hastalığının önemli ve gözden kaçabilen komplikasyonlarından birisi de malnutrisyondur. Beslenme durumu demans tanısı konan bireylerde ilk görüşmede ve hastalığın takiplerinde düzenli olarak değerlendirilmelidir. Malnütrisyonun engellenmesi ve fonksiyonel bağımsızlığın sürdürülebilmesi için hastanın yeterli ve dengeli beslenmesi sağlanmalıdır. Beslenmenin demansa olan etkilerinin incelenmesi için daha fazla çalışma yapılması tıbbi beslenme tedavisine fayda sağlayacaktır.

Anahtar kelimeler: Beslenme durumu, demans, geriatri, yaşl, beslenme

Received / Geliş tarihi: 20.02.2021, Accepted / Kabul tarihi: 19.06.2021

${ }^{1}$ Acıbadem Mehmet Ali Aydınlar Üniversitesi Beslenme ve Diyetetik Bölümü, İSTANBUL (ORCID: 0000-0002-2790-1525)

${ }^{2}$ İzmir Demokrasi Üniversitesi Beslenme ve Diyetetik Bölümü, İZMIR (ORCID: 0000-0002-3625-4761)

*Address for Correspondence / Yazışma Adresi: İzmir Demokrasi Üniversitesi Beslenme ve Diyetetik Bölümü, İzmir -TÜRKIYE,

E-mail: dyt_esen@yahoo.com

Tel: $+905 \overline{42} 6220151$

Yılmaz G, Karaca KE. Demans Tanısı Alan ve Almayan Geriatrik Bireylerin Beslenme Durumlarının Değerlendirilmesi. TJFMPC, 2021;15(3): 521-530.

DOI: $10.21763 / \mathrm{tjfmpc} .883284$ 


\section{Gİiş̧}

Dünya nüfusunun, 1980 yılında 382 milyonu 60 yaş ve üzerinde iken 2017 yılında bu rakamın 962 milyona ulaştığı bilinmektedir. Yaşlı nüfusun ise 2050 yılında iki kat artarak 2.1 milyar seviyelerine ulaşması ayrıca 2030 yılında yaşlı nüfusun 10 yaş altındaki çocuklardan daha fazla olması beklenilmektedir. ${ }^{1}$ Türkiye'de ise yaşlı nüfus olarak kabul edilen 65 ve daha yukarı yaştaki nüfus, 2014 yılında 6 milyon 192 bin 962 kişi iken son beş yılda \%21,9 artarak 2019 y1lında 7 milyon 550 bin 727 kişiye ulaşmıştır. Yaşlı nüfusun toplam nüfus içindeki oranı ise 2014 yılında \%8,0 iken, 2019 yılında \%9,1'e yükselmiştir. Yaşlı nüfusun 2019 yılında \%44,2'sini erkek nüfus, \%55,8'ini kadın bireyler oluşturmaktadır. ${ }^{2}$

Dünya genelinde 50 milyona yakın insan demans ile yaşamakta ve bu sayının 20 yıl içerisinde ikiye katlanması, 2030 yılında 74.7 milyona ve 2050 yılında 131.5 milyona ulaşması beklenmektedir. $^{3}$ Demans, bilişsel işlevlerin beyindeki bir bozukluğa bağlı olarak kaybıdır, ilerleyici bir süreçtir ve beyinde bellek, düşünme, yönlendirme, anlama, hesaplama, öğrenme kapasitesi, dil ve muhakeme gibi yüksek kortikal fonksiyonların bozulduğu bir hastalıktır. ${ }^{4}$ Demans beyni etkileyen farkl1 etiyolojilerden kaynaklanabilen bir sendromdur. Demans türleri ve nedenleri farklı yaklaşımlar kullanılarak sınıflandırılabilmektedir. Demansın altta yatan etiyoloji ve disfonksiyon mekanizmasına bağlı olarak primer dejeneratif demans ve ikincil (veya semptomatik) demans olmak üzere iki ana kategoriye ayrılmaktadır. ${ }^{5}$ Demansın birçok farklı türü bulunmaktadır. Alzheimer demans (AD) en yaygın demans türüdür. Alzheimer hastalığını sirasiyla vasküler demans (VaD) ve Lewy cisimcikli demans (LCD) izlemektedir. Demans genellikle komorbiditenin sık görüldüğü 65 yaş üzeri bireylerde görülmektedir. ${ }^{6}$

Demans ile ilişkili faktörler arasında yaş, cinsiyet, genetik faktörler, komorbidite, çevresel faktörler ve yaşam biçimi bulunmaktadır. Koruyucu faktörler arasında yüksek eğitim seviyesi, 1lımlı derecede alkol tüketimi, antienflamatuar ilaç kullanımı ve beslenme tedavisi sayllabilmektedir. Demansta vücut ağırlığı kaybının altında yatan mekanizmaların birçok nedeni bulunmaktadır fakat henüz net olarak anlaşılmamıştır. Demansla ilişkili beyin atrofisinin, iştah düzenleme ve beslenme davranışında yer alan beynin bölgelerini etkileyebileceği, vücut ağırlığındaki azalmanın azalan besin alımı ile ilgili olabileceği düşünülmektedir. ${ }^{7,8}$

Demansta malnütrisyon, vücut ağırlığında azalma, bilişsel gerileme ve demans arasında gözlenen ilişkileri açıklamak için birçok teori ortaya atılmıştır. İlk olarak demans hastaları, bilişsel fonksiyonlarının azalması nedeni ile azalan enerji alımından dolayı vücut ağırlığında azalma yaşayabilmekte, bu durum yemek yemeyi unutabilmelerine veya reddetmelerine neden olabilmektedir. İkincisi koku ve tat alma gibi duyusal değişiklikler nedeniyle kolinerjik açıkların sonucu olarak ağırlık kaybı görülebilmektedir. Disfaji veya yutma güçlüğü enerji alımının azalmasina neden olabilmekte ayrica bazal metabolizma hızında \%10'luk bir artış olarak tanımlanan hipermetabolizmin de vücut ağırlığında azalmaya neden olabileceği düşünülmektedir. Demanstaki nöroendokrin düzensizliği de vücut ağırlığındaki azalmaya sebep olabilecek başka bir faktördür. ${ }^{8}$

Enerji ve çeşitli besin ögeleri, beyin metabolizması ve işlevinde önemli rol oynamaktadır. Demans gelişiminde önemli patolojik mekanizmalar olarak kabul edilen vasküler hasar, oksidatif stres ve enflamatuar süreçler belirli besin ögeleri tarafından modüle edilmektedir. Tiamin, folik asit ve B12 gibi mikro besin ögelerinin yetersizliklerinin bilişsel bozulmaya neden olabileceği düşünülmektedir. Epidemiyolojik çalışmalar sağlıklı yaşlı bireylerde belirli beslenme modellerinin demans ve bilişsel düşüş riskini azaltabileceğini ve tam tersi durumlarda olumsuz beslenme modellerinin demans ve bilişsel düşüş riskini arttırabileceğini göstermektedir. Bununla birlikte belirli beslenme alışkanlıklarının veya belirli besin ögelerinin yetersiz alımının hastalığın ilerlemesine neden olduğunu gösteren daha çok çalışmaya ihtiyaç vardır. ${ }^{9}$ Özetle beslenme sorunları hastalığın bir parçası olarak görülmekte ve demanslı bireylerin malnütrisyon riskinin yüksek olduğu düşünülmektedir.

$\mathrm{Bu}$ çalışmada; demans tanısı alan ve almayan geriatrik bireylerin malnütrisyon ve beslenme durumlarını değerlendirmek, geriatrik bireylerin el kavrama gücü değerlendirilip demans tanıs1 alan ve demans tanısı almayan bireyler arasındaki farkı incelemek amaçlanmıştır.

\section{YÖNTEM}

\section{Araştırma Yeri, Zamanı ve Örneklem Seçimi}

$\mathrm{Bu}$ araştırma, Acıbadem Mehmet Ali Aydınlar Üniversitesi ve Acıbadem Sağlık Kuruluşları Tıbbi Araştırma Etik Kurulu Kararı alındıktan sonra Kastamonu Devlet Hastanesi Nöroloji Polikliniğine başvuran 51 demans tanısı alan ve 51 demans tanısı almayan 102 geriatrik birey dahil edilerek yürütülmüştür. Araştırmaya, 65 yaş altında olan ve ağıdan beslenemeyen bireyler dahil edilmemiştir. 
Araştırma, Acibadem Üniversitesi ve Acıbadem Sağlık Kuruluşları Tıbbi Araştırma Etik Kurulundan (ATADEK) 15.02.2018 tarih 20182/31 karar numarası ile tıbbi etik yönden uygun bulunmuştur. Her hastaya bilgilendirilmiş gönüllü olur formu okunmuş ve imzalatılarak alınmıştır.

\section{Veri Toplama Araçları}

Araştırmacı tarafından hastalara, yüz yüze görüşme yöntemi ile Beslenme Risk Taraması (NSI), Katz Günlük Yaşam Aktiviteleri Ölçeği (GYA), Lawton\&BrodyEnstrümental Günlük Yaşam Aktiviteleri Ölçeği (EGYA), EAT-26 Yeme Davranış1 Ölçeklerini içeren anket formu uygulanmış, 24 saatlik besin tüketim kayıtları ve bazı antropometrik ölçümleri alınmıştır. Ayrıca anket araştırmaya katılan bireylerin yaş, cinsiyet, medeni durumu ve eğitim seviyesi gibi sosyodemografik özelliklerini de içermektedir.

\section{Beslenme Risk Taraması- NSI}

Amerikan Diyetetik Derneği, Amerikan Aile Hekimliği Akademisi ve Ulusal Yaşlılık Konseyi tarafından geliştirilen 'Beslenme Risk TaramasıNSI (Nutrition Screening Initiative)' toplumda yaşayan yaşlı bireylerde yetersiz beslenmeye neden olan temel beslenme bilgilerine ulaşılmasını sağlamaktadır. Özgüneş ve arkadaşları tarafından 2013 yılında yapılan çalışmada meyve-sebze tüketimi, öğün sayısı, beslenmeyi etkileyecek ağız ve diş problemi varlığı, alkol tüketimi, maddi imkanlar, ilaç kullanımı ve son zamanlarda yaşanan ağırlık kaybı gibi soruları içermektedir. 0-2 puan düşük risk, 3-5 puan orta risk, 6 ve üzeri yüksek risk olarak tanımlanmaktadır. ${ }^{10,11}$

\section{Katz Günlük Yaşam Aktiviteleri Ölçeği- KatzGYA}

Yaşlanma ile birlikte fonksiyonel yeteneklerde azalma görülmektedir. Fonksiyonel yeteneklerde azalma bir hastalığın ilk belirtisi olabilmektedir. $\mathrm{Bu}$ nedenle, fonksiyonel durumun anlaşılması geriatrik değerlendirmenin önemli bir bileşenidir. İşlevsel durumu belirlemek için birçok ölçek geliştirilmiş ve kullanılmıştır. Günlük yaşam aktivitelerinin değerlendirilmesinde kullanılan ölçekler arasında, Katz GYA klinik uygulamada en iyi bilinen ve klinik çalışmalarda en yaygın kullanılan ölçeklerdendir. Katz GYA, 1960'larda Katz ve arkadaşları tarafından geliştirilmiştir. ${ }^{12}$ Türkçe geçerlilik güvenilirlik çalışması Arık ve arkadaşları tarafindan yapılan Katz GYA banyo, giyinme, tuvalet, hareket, üriner-fekal kontrol ve beslenme aktiviteleri ile ilgili bilgileri içeren altı sorudan oluşmaktadır. 0-2 puan fiziksel bağımlı, 3-5 puan orta derecede fiziksel bağımlı ve 6 puan fiziksel bağımsız olarak değerlendirilmektedir. ${ }^{13}$

\section{Lawton\&BrodyEnstrümental Günlük Yaşam} Aktiviteleri

Enstrümental günlük yaşam aktiviteleri ölçeği (EGYA) Lawton ve Brody tarafından tanımlanmış olan EGYA indeksi kullanilarak değerlendirilmiştir. ${ }^{14}$ Hem yurtdışında hem de ülkemizde uzun süredir yaygın olarak kullanılan bu indeks telefon kullanma, yemek hazırlama, alışveriş yapma, çamaşır yıkama, ulaşım aracına binebilme, ilaçları kullanabilme ve para iadesi ile ilgili bilgileri içeren 8 sorudan oluşmaktadır. 0-8 puan bağımlı, 916 puan yan bağımlı, 17-24 puan ise bağımsız olarak tanımlanmıştır. ${ }^{15,16}$

\section{EAT-26 Yeme Tutum Testi}

Yeme tutum testi yeme davranışı bozukluğu riskini değerlendirmek için kullanılmaktadır. Ergüney Okumuş ve Sertel Berk tarafından ölçeğin Türkçe geçerlilik güvenilirlik çalışması yapılmıştır. EAT26 testinde sonuçlar, 26 maddenin puanlarının toplamının değerlendirilmesi ile belirlenir. Test sonucunda 0 ile 53 arasında değerler alınabilir, 20 puan EAT-26 için kesim noktasıdır. 20 ve üzeri puan alan bireyler 'anormal yeme davranışı' olan bireyler olarak sinıflandırılırken, 20'nin altında puan alanlar ise 'normal yeme davranıssı' olan bireyler olarak değerlendirilmektedir. ${ }^{17,18}$

\section{Antropometrik Ölçümler}

Bireylerin vücut ağırlığı $(\mathrm{kg})$, boy uzunluğu $(\mathrm{cm})$, antropometrik ölçümleri alınmış ve araştırmacı tarafından kaydedilmiștir. Araştırmaya katılan bireylerin vücut ağırlık ölçümü OMRON- HBF511T-E marka cihaz ile boy ölçümü MESİTAŞ marka boy ölçer ile yapılmıştır. Boy uzunluğu ölçülürken ayaklar yan yana ve baş Frankfort düzlemde (göz üçgeni ve kulak kepçesi üstü aynı hizada) iken bireyin dik durması sağlanarak yönteme uygun şekilde ölçülmüştür. Bireylerin Üst Orta Kol Çevresi (ÜKÇ) ve Baldır Çevresi (BÇ) ölçümleri araştırmacı tarafından alınarak kaydedilmiştir. Katılımcılar ÜKÇ değerlerine göre erkekler 23, kadınlarda $22 \mathrm{~cm}$ altı azalmış kas kütlesi olarak değerlendirilmiştir. BÇ $31 \mathrm{~cm}$ 'nin altında olması azalmış kas kütlesi olarak değerlendirilmiştir. Beden kütle indeksi (BKİ), vücut ağırlığ 1 boy uzunluğu $\left(\mathrm{kg} / \mathrm{m}^{2}\right)$ denkleminden hesaplanmıştır.

Bireylerin el kavrama gücü değerlendirilmesi amacıyla CAMRY marka el dinamometresi ile değerlendirilmiştir. Katılımcılara hangi eli aktif olarak kullandığı sorulmuş ve baskın el ile ölçüm yapılmıștır. Katılımcılar sandalyeye oturtulup dirsekleri masaya konarak, kolları yere paralel olacak şekilde 90 derece fleksiyonda tutulup; 1 dakikalık dinlenme periyotları ile üçer kez ölçüm yapılmıștır. Üç ölçümün ortalaması 
alınarak 65-69 yaş arası erkeklerde 28,2'nin altı düşük, 28,2-44,0 arası normal; 70-99 yaş arası erkeklerde 21,3'ün altı düşük, 21,3-35,1 aras1 normal kabul edilmiştir. Kadın katılımcılarda 65-69 yaş arası 15,4'ün altı düşük, 15,4-27,2 arası normal; 70-99 yaş arası kadın katılımcılarda 14,7'nin altı düşük, 14,7- 24,5 arası normal olarak değerlendirilmiştir.

\section{Bireylerin Besin Tüketim Durumlarının Saptanması}

Bireylerin günlük besin tüketimi ile enerji ve besin ögesi saptanması amacıyla 3 günlük besin tüketim kaydı tutulmuştur. Günlük tüketilen enerji ve besin ögeleri değerleri Beslenme Bilgi Sistemleri (BEBİS) programı ile hesaplanmıştır. Bireylerin günlük enerji ve besin ögesi alım miktarları referans alım düzeyi (Dietary Reference Intake: DRI) değerleri ile karşılaştırılmış, ve DRI karşılama yüzdeleri (\%DRI) hesaplanmıştır.

\section{Verilerin İstatistiksel Değerlendirmesi}

Çalışmada elde edilen bulgular değerlendirilirken, istatistiksel analizler için SPSS 22.0 İstatistik paket programı, niteliksel verilerin karşılaştırılmasında ise Pearson Ki-Kare testi ve Fisher Exact testi kullanılmıştır. Sonuçlar \%95 güven aralığında, $\mathrm{p}<0,05$ anlamlılık düzeyinde değerlendirilmiştir. Niceliksel verilerin normal dağılıma uygunluğu için Kolmogorov-Simirnov testi kullanılmıştır. Nicel verilerin karşılaştırılması Mann-Whitney U testi, Kruskal Wallis testi ve Bağımsız $T$ testi ile değerlendirilmiş, katılımcıların anketteki sorulara verdikleri cevaplara ilişkin betimsel istatistikler ve olumsallık tabloları verilmiştir.

\section{BULGULAR}

Çalışmadaki demans tanısı alan bireylerin\% \% 58,8 'si $(n=30)$ kadın, \%41,2'si(n=21) erkek, demans tanıs1 almayan bireylerin ise \%70,5' $\mathrm{i}(\mathrm{n}=36)$ kadın, \%29,5'i (n=15)erkektir. Demans tanıs1 alan bireylerin yaş ortalaması $78.84 \pm 7.844$ yıl, demans tanısı almayan bireylerin yaş ortalaması $75.02 \pm$ 72,26 y1l olarak saptanmıştır. Tablo 1'de görüldüğü gibi çalışmaya katılan bireylerin cinsiyet, medeni durum, eğitim durumu ve kiminle yaşadıkları ile demans arasında istatistiksel olarak anlamlı bir fark bulunmamıştır $\quad(p>0.05)$ Ancak yaş arttıkça demansın arttığ 1 belirlenmiştir $(\mathrm{p}=0,012)$.

Tablo 2'de çalışmaya katılan bireylerin bazı antropometrik ölçümleri ile demans arasındaki ilişki gösterilmiştir. Demanslı olmayan bireylerin; vücut ağırlığı ve vücut yağ oranı değerleri demanslı bireylerin değerlerinden daha yüksektir (sırasıyla $\mathrm{p}=0,034 ; \mathrm{p}=0,004)$.

Demans tanısı alan ve almayan kadın ve erkek bireylerin günlük tükettikleri ortalama enerji ve makro besin öğeleri değerleri Tablo 3 'de verilmiştir. Demans tanısı alan kadınların besinler ile aldıkları çoklu doymamış yağ asitleri miktarı daha düşüktür $(p=0,034)$. Demans tanısı alan erkeklerin tükettikleri enerji, karbonhidrat, protein ve yağ miktarları daha düşüktür (sırasıyla; $p=0,006$; $p=0,015 ; p=0,12 ; p=0,017)$. Demans tanisı alan ve almayan kadınların tükettikleri enerji, karbonhidrat, protein ve yağ miktarları arasında anlamlı bir ilişki bulunmamıştır ancak demans tanısı alan kadınların karbonhidrat tüketimleri daha yüksektir.

Çalışmaya katılan bireylerin Beslenme Risk Taraması değerleri ile demans durumları Tablo 4'degösterilmiştir.NSI değerleri ile demans arasında anlamlı bir ilişki vardır $(\mathrm{p}=0,001)$. Demans tanısı alan bireylerin $\% 7,8^{\prime} \mathrm{i}$ düşük risk NSI değerine sahipken, demans tanısı almayan bireylerin \%24,5'i düşük risk NSI değerine sahiptir.

Tablo 5'dedemans tanısı alan ve almayan bireylerin KatzGYA, EGYA, EAT-26 ve el kavrama gücü değerleri ile demans durumları arasındaki ilişki verilmiştir. Demans tanısı almayan bireylerin Katz Günlük Yaşam Aktiviteleri, Lawton\&Brody Enstrümental Günlük Yaşam Aktiviteleri ve Eat-26 Yeme Tutum Testi değerleri demans tanısı almayan bireylere göre daha yüksektir (sırasıyla: $\mathrm{p}=0,000 ; \mathrm{p}=0,000 ; \mathrm{p}=0,034$ ).

Tablo 1. Bireylerin sosyo-demografik özellikleri ile demans arasındaki ilişki

\begin{tabular}{|c|c|c|c|}
\hline & Demans tanısı almayan & Demans tanısı alan & \\
Sosyo Demografik Özellikler & $\mathrm{n}=51$ & $\mathrm{n}=51$ & $\mathrm{p}$ \\
& $\bar{X} \pm \mathrm{SS}$ & $\bar{X} \pm \mathrm{SS}$ & $0,01^{*}$ \\
\hline Yaş & $75,02 \pm 7,23$ & $78,84 \pm 7,84$ & \\
\hline & $\mathrm{n}(\%)$ & $\mathrm{n} \mathrm{( \% )}$ & \\
\hline
\end{tabular}




\begin{tabular}{|c|c|c|c|c|}
\hline \multirow{2}{*}{ Cinsiyetiniz } & Kadın & $36(35,3 \%)$ & $30(29,4 \%)$ & \multirow{2}{*}{0,30} \\
\hline & Erkek & $15(14,7 \%)$ & $21(20,6 \%)$ & \\
\hline \multirow{3}{*}{$\begin{array}{c}\text { Medeni } \\
\text { Durumunuz }\end{array}$} & Bekar & $3(2,9 \%)$ & $0(0,0 \%)$ & \multirow{3}{*}{0,16} \\
\hline & Evli & $29(28,4 \%)$ & $27(26,5 \%)$ & \\
\hline & Dul/Boşanmış & $19(18,6 \%)$ & $24(23,5 \%)$ & \\
\hline \multirow{5}{*}{$\begin{array}{c}\text { Eğitim } \\
\text { Durumunuz }\end{array}$} & Okur-Yazar değil & $20(19,6 \%)$ & $23(22,5 \%)$ & \multirow{5}{*}{0,35} \\
\hline & Okur-yazar & $6(5,9 \%)$ & $12(11,8 \%)$ & \\
\hline & İlkokul mezunu & $21(20,6 \%)$ & $13(12,7 \%)$ & \\
\hline & Ortaokul mezunu & $2(2,0 \%)$ & $1(1,0 \%)$ & \\
\hline & Lise mezunu & $2(2,0 \%)$ & $2(2,0 \%)$ & \\
\hline \multirow{5}{*}{$\begin{array}{c}\text { Kiminle } \\
\text { yaşıryorsunuz }\end{array}$} & Yalnız & $5(4,9 \%)$ & $1(1,0 \%)$ & \multirow{5}{*}{0,28} \\
\hline & Eşiyle & $15(14,7 \%)$ & $17(16,7 \%)$ & \\
\hline & Eşi ve çocuklarıyla & $12(11,8 \%)$ & $10(9,8 \%)$ & \\
\hline & Torunları/çocukları & $19(18,6 \%)$ & $21(20,6 \%)$ & \\
\hline & Bakıcı & $0(0,0 \%)$ & $2(2,0 \%)$ & \\
\hline
\end{tabular}

* Ki-kare ve FisherExact testi

$* * \mathbf{p}<0,05$

Tablo 2. Bireylerin bazı antropometrik ölçümleri ile demans arasındaki ilişki

\begin{tabular}{|c|c|c|c|}
\hline \multirow{3}{*}{$\begin{array}{l}\text { Antropometrik } \\
\text { Ölçümler }\end{array}$} & Demans tanısı almayan & Demans tanis1 alan & \multirow{3}{*}{$\mathrm{p}$} \\
\hline & $\mathrm{n}=51$ & $\mathrm{n}=51$ & \\
\hline & $\bar{X} \pm \mathrm{SS}$ & $\bar{X} \pm \mathrm{SS}$ & \\
\hline Vücut Ağırlığ1 & $72,76 \pm 14,97$ & $66,90 \pm 12,54$ & $0,03 *$ \\
\hline Vücut Yağ Oranı & $0,34 \pm 0,07$ & $0,30 \pm 0,07$ & $0,004^{*}$ \\
\hline Bel Çevresi & $101,50 \pm 9,51$ & $99,37 \pm 9,61$ & 0,24 \\
\hline \multicolumn{4}{|l|}{ Kadın } \\
\hline Baldır Çevresi & $34,50 \pm 3,85$ & $33,60 \pm 3,87$ & 0,24 \\
\hline Üst Kol Çevresi & $29,92 \pm 4,21$ & $28,50 \pm 2,62$ & 0,06 \\
\hline \multicolumn{4}{|l|}{ Erkek } \\
\hline Baldır Çevresi & $36,47 \pm 3,85$ & $33,76 \pm 3,77$ & 0,05 \\
\hline \multirow[t]{2}{*}{ Üst Kol Çevresi } & $29,87 \pm 3,36$ & $28,76 \pm 4,86$ & 0,92 \\
\hline & & $\mathrm{n}(\%)$ & \\
\hline
\end{tabular}




\begin{tabular}{cllll}
\hline & Normal Kilolu & $8(7,8 \%)$ & $16(15,7 \%)$ & \\
& Fazla Kilolu & $21(20,6 \%)$ & $25(24,5 \%)$ & \\
BKİ & I.derece obez & $16(15,7 \%)$ & $5(4,9 \%)$ & $0,02 *$ \\
& II.derece obez & $2(2,0 \%)$ & $4(3,9 \%)$ & \\
& III.derece obez & $4(3,9 \%)$ & $1(1,0 \%)$ & \\
\hline Son 6 ayda & Evet & $16(15,7 \%)$ & $24(23,5 \%)$ & \\
kilonuzda değişiklik & Hayır & $28(27,5 \%)$ & $12(11,8 \%)$ & $0,004 *$ \\
oldu mu & Bilmiyorum & $7(6,9 \%)$ & $15(14,7 \%)$ & \\
\hline
\end{tabular}

*Bağımsız T testi

$* * \mathrm{p}<0,05$

Tablo 3. Demans tanısı alan ve almayan bireylerin cinsiyete göre günlük tükettikleri ortalama enerji ve makro besin öğeleri

\begin{tabular}{|c|c|c|c|c|c|c|}
\hline & $\begin{array}{l}\text { Kadın Demans } \\
\text { Tanısı Alan }\end{array}$ & $\begin{array}{l}\text { Kadın Demans } \\
\text { Tanısı } \\
\text { Almayan }\end{array}$ & & $\begin{array}{l}\text { Erkek Demans } \\
\text { Tanısı Alan }\end{array}$ & $\begin{array}{l}\text { Erkek Demans } \\
\text { Tanısı Almayan }\end{array}$ & \\
\hline & $\overline{\mathbf{X}} \pm \mathbf{S S}$ & $\overline{\mathbf{X}} \pm \mathbf{S S}$ & $\mathbf{p}$ & $\overline{\mathbf{X}} \pm \mathbf{S S}$ & $\overline{\mathbf{X}} \pm \mathbf{S S}$ & $\mathbf{p}$ \\
\hline $\begin{array}{l}\text { Günlük } \\
\text { Enerji (kkal) }\end{array}$ & $1086,6 \pm 217,69$ & $1096,10 \pm 213,06$ & 0,86 & $1274,09 \pm 288,52$ & $1607,59 \pm 398,66$ & 0,006 \\
\hline $\mathrm{Su}(\mathrm{ml})$ & $2006,82 \pm 590,92$ & $2006,87 \pm 668,44$ & 1,00 & $2308,13 \pm 656,67$ & $2932,70 \pm 997,20$ & 0,07 \\
\hline Protein $(\mathrm{g})$ & $43,39 \pm 8,03$ & $44,64 \pm 11,26$ & 0,76 & $50,60 \pm 13,11$ & $64,97 \pm 15,47$ & 0,01 \\
\hline Yăg $(g)$ & $41,42 \pm 8,16$ & $45,34 \pm 10,08$ & 0,16 & $49,13 \pm 13,15$ & $61,30 \pm 15,97$ & $\mathbf{0 , 0 1}$ \\
\hline $\begin{array}{l}\text { Karbonhidra } \\
\mathrm{t}(\mathrm{g})\end{array}$ & $131,32 \pm 34,19$ & $123,91 \pm 30,70$ & 0,36 & $153,31 \pm 40,17$ & $193,54 \pm 54,34$ & 0,01 \\
\hline Posa (g) & $17,00 \pm 3,35$ & $16,90 \pm 4,27$ & 0,92 & $19,89 \pm 5,78$ & $22,99 \pm 4,89$ & 0,10 \\
\hline $\begin{array}{l}\text { Çoklu } \\
\text { doymamış } \\
\text { yağ asidi (g) }\end{array}$ & $5,92 \pm 1,60$ & $7,28 \pm 2,54$ & $\mathbf{0 , 0 3}$ & $8,09 \pm 2,56$ & $9,03 \pm 2,97$ & 0,31 \\
\hline $\begin{array}{l}\text { E vitamini } \\
(\mathrm{mg})\end{array}$ & $5,56 \pm 1,36$ & $6,53 \pm 2,21$ & 0,10 & $7,24 \pm 2,80$ & $7,72 \pm 2,61$ & 0,42 \\
\hline $\begin{array}{l}\text { B1 Vitamini } \\
(\mathrm{mg})\end{array}$ & $0,76 \pm 0,17$ & $0,74 \pm 0,19$ & 0,66 & $0,80 \pm 0,24$ & $0,93 \pm 0,26$ & 0,20 \\
\hline $\begin{array}{l}\text { B2 Vitamini } \\
(\mathrm{mg})\end{array}$ & $0,94 \pm 0,17$ & $0,95 \pm 0,22$ & 0,72 & $0,99 \pm 0,22$ & $1,21 \pm 0,30$ & 0,02 \\
\hline $\begin{array}{l}\text { B6 Vitamini } \\
(\mathrm{mg})\end{array}$ & $0,94 \pm 0,20$ & $0,97 \pm 0,27$ & 0,62 & $0,97 \pm 0,25$ & $1,14 \pm 0,29$ & 0,05 \\
\hline $\begin{array}{l}\text { B12 } \\
\text { Vitamini } \\
(\mathrm{mg})\end{array}$ & $2,64 \pm 1,06$ & $2,68 \pm 1,38$ & 0,57 & $2,96 \pm 1,73$ & $3,73 \pm 1,26$ & $\mathbf{0 , 0 3}$ \\
\hline
\end{tabular}




\begin{tabular}{|c|c|c|c|c|c|c|}
\hline Folat $(\mu \mathrm{g})$ & $250,05 \pm 51.08$ & $259,28 \pm 66,59$ & 0,54 & $270,49 \pm 63,68$ & $310,82 \pm 90,57$ & 0,12 \\
\hline $\begin{array}{l}\text { Sodyum } \\
(\mathrm{mg})\end{array}$ & $2327,23 \pm 586,09$ & $2615,31 \pm 660,13$ & 0,07 & $3104,84 \pm 1238,21$ & $3834,82 \pm 1174,73$ & $\mathbf{0 , 0 1}$ \\
\hline $\begin{array}{l}\text { Potasyum } \\
(\mathrm{mg})\end{array}$ & $1605,47 \pm 264,04$ & $1649,85 \pm 393,55$ & 0,59 & $1743,65 \pm 338,08$ & $2146,39 \pm 479,32$ & $\overline{0,006}$ \\
\hline $\begin{array}{l}\text { Kalsiyum } \\
\text { (mg) }\end{array}$ & $610,75 \pm 113,89$ & $639,80 \pm 121,02$ & 0,32 & $625,03 \pm 153,88$ & $851,81 \pm 181,68$ & $\mathbf{0 , 0 0 0}$ \\
\hline $\begin{array}{l}\text { Magnezyum } \\
(\mathrm{mg})\end{array}$ & $229,29 \pm 42,27$ & $225,60 \pm 49,41$ & 0,75 & $236,22 \pm 63,20$ & $288,26 \pm 66,48$ & 0,02 \\
\hline Fosfor (mg) & $828,09 \pm 141,81$ & $821,77 \pm 162,86$ & 0,87 & $866,87 \pm 195,36$ & & $\mathbf{0 , 0 0 5}$ \\
\hline
\end{tabular}

Tablo 4. Demans tanısı alan ve almayan bireylerin Beslenme Risk Taraması değerleri ile demans arasındaki ilişki

\begin{tabular}{|l|c|c|c|c|}
\hline \multicolumn{2}{|c|}{} & $\begin{array}{c}\text { Demans tanıs1 almayan } \\
\mathrm{n}=51\end{array}$ & $\begin{array}{c}\text { Demans tanısı alan } \\
\mathrm{n}=51\end{array}$ & $\mathrm{p}$ \\
\hline \multirow{3}{*}{ NSI toplam } & Düşük Risk & $25(24,5 \%)$ & $8(7,8 \%)$ & \\
\cline { 2 - 4 } & Orta Risk & $14(13,7 \%)$ & $26(25,5 \%)$ & \multirow{2}{*}{$0,001 *$} \\
\cline { 2 - 4 } & Yüksek Risk & $12(11,8 \%)$ & $17(16,7 \%)$ & \\
\hline $\begin{array}{l}* \text { *Ki-kare testi } \\
* * 0,05\end{array}$ & & & & \\
\hline
\end{tabular}

Tablo 5. Demans tanısı alan ve almayan bireylerin KatzGYA, EGYA, EAT-26 ve el kavrama gücü değerleri ile demans arasındaki ilişki

\begin{tabular}{|c|c|c|c|}
\hline & Demans tanısı almayan & Demans tanisı alan & \\
& $\mathrm{n}=51$ & $\mathrm{n}=51$ & $\mathrm{p}$ \\
& $\bar{X} \pm \mathrm{SS}$ & $\bar{X} \pm \mathrm{SS}$ & \\
\hline Katz GYA & $5,43 \pm 0,92$ & $4,04 \pm 1,47$ & $0,000^{*}$ \\
\hline Lawton\&Brody EGYA & $5,00 \pm 2,57$ & $2,12 \pm 2,41$ & $0,000^{*}$ \\
\hline EAT-26 & $5,57 \pm 3,23$ & $4,25 \pm 2,6$ & $0,03^{*}$ \\
\hline El Kavrama Gücü & $17,89 \pm 6,54$ & $19,56 \pm 6,48$ & 0,15 \\
\hline
\end{tabular}

*Mann-Whitney U testi

$* * \mathrm{p}<0,05$

\section{TARTIŞMA}

Demans bilişsel ve fonksiyonel yeteneklerin azalması ile ilişkili ilerleyici bir sendromdur. Fonksiyonel bağımsızlığı kaybı ve ölümle sonuçlanabilmektedir. Hastanın fonksiyonel bağımsızlığının sürdürülmesi, ailelerin veya bakım veren kişilerin yükünün azaltılması için değiştirilebilir faktörlerin belirlenmesi oldukça önem taşımaktadır. Son zamanlarda demanslı 
bireylerin bilişsel, nöropsikiyatrik ve fonksiyonel bağımsızlıkları ile beslenme durumları üzerinde durulmaktadır. ${ }^{19}$

Cinsiyet, demans için yaşlı bireyler arasında risk faktörlerinden bir tanesi olarak tanımlanmaktadır. ${ }^{9}$ Ravaglia ve Lopez-pousa'nın yaptıkları araştırmalarda İtalyan ve İspanyol toplumlarında demans ve cinsiyet arasinda anlamlı bir ilişki olmadığı bildirilmiştir. ${ }^{20}$ Cinsiyet ve demans arasındaki ilişkinin cinsiyet hormonları, yaşam tarzı, etnik köken ve cinsiyete bağlı genlerin poliformizmi gibi etmenleri de göz önünde bulundurarak incelenmesi gerekmektedir. ${ }^{9} \mathrm{Bu}$ çalışmada da cinsiyet ile demans hastalığı arasında istatistiksel olarak anlamlı bir farklılığın olmadığ1 belirlenmiştir. $\mathrm{Bu}$ durum, demans etyolojisinin multifaktöriel olmasından kaynaklanmakta ve sadece cinsiyetin bir neden olarak düşünülmemesi gerekliliğini desteklemektedir.

Galesi ve ark, yaptıkları bir çalışmada demans tanısı alan ve almayan bireylerin beslenme durumları karşılaştırılmışlar ve çalışmanın sonucuna göre demans beslenme durumu ile ilişskilendirilmiştir ancak enerji ve besin alımları ile ilişskilendirilmemiştir. Demans tanısı alan bireylerin daha fazla besin gereksinimine ihtiyaç duyduğu öne sürülmüştür. ${ }^{21}$ Garzani ve Pires, demans ve beslenme durumu arasındaki ilişkiyi besin tüketimi ile değil fiziksel aktivite ve ajitasyon gibi fazla enerji gerektiren aktivitelerden kaynaklanan ağırlık kaybı ile açıklamıştır. ${ }^{22} \mathrm{Bu}$ nedenle demans tanısı alan bireylerde enerji harcanımının göz ard1 edilmemesi gerekmektedir. Bizim çalışmamızda ise enerji, karbonhidrat, protein ve yağ alımları cinsiyete göre farklılık göstermiştir. Erkeklerde demans tanısı almayan bireylerde bu değerlerin yüksek olduğu kadınlarda ise anlamlı bir farklılık olmadığı belirlenmiştir.

Walter ve ark, yaptıkları randomize kontrollü bir çalışmada $400 \mathrm{mcg}$ folik asit ve 100 mcg B12 vitamini takviyesi verilen grup ve plasebo grubun bilişsel işlevlerindeki değişim karşılaştırılmıştır. Çalışmanın sonucunda folik asit ve B12 vitamini takviyesi alan grupta bilişsel işlevde ilerleme kaydedildiği gözlenmiştir. ${ }^{23}$ Ancak Ford ve ark, 75 yaş üstü 299 erkek birey ile çift kör kontrollü yaptıkları çalışmada; 2 yıl boyunca $2 \mathrm{mg}$ folik asit, $25 \mathrm{mg}$ B6 ve $400 \mathrm{mcg}$ B12 vitamini takviyesi verilmiştir. Çalışmanın sonucunda B12, B6 ve folik asit takviyesinin yaşlı erkek bireylerde bilişsel işlev üzerinde etkisi görülmediği veya demans riskini azaltmadığ 1 belirtilmiştir. ${ }^{24} \mathrm{Bu}$ çalışmada ise B1, B2, B6 ve B12 vitamini değerlerinin demans hastalığına göre anlamlı bir farklılığın olmadı̆̆ 1 belirlenmiştir $(p>0,05)$. Besin ögesi değerlerinin istatistiksel olarak anlamlı olmaması bireylerin tükettikleri besinleri hatırlamamaları, tükettikleri besinin miktarını ve türünü net olarak aktaramamaları ve demans tanısı alan bireylerin bir kısmının aile ve bakım sağlayan kişiler tarafından beslenmesi olabilir.

Malnütrisyon yaşlılık döneminde sık karşılaşılan klinik bir tablodur. Ancak bu riskin demanslı bireylerde daha yüksek olduğu bilinmektedir. Vücut ağırlığında azalma malnütrisyonun iyi bir göstergesidir. Demans şiddetindeki artış ve mortalite ilişkilendirilmektedir. Ağırlık kaybında yaşanan \%8'lik artış mortalitenin artması ile ilişkilendirilmektedir. ${ }^{25}$ Meyer ve ark, 45 demanslı birey ile yaptıkları çalışmada katılımcıların \%80,6's1 MNA'ya göre malnütrisyon riskine sahip olarak bulunmuştur. ${ }^{26} \mathrm{Bu}$ çalışmada malnütrisyon tarama aracı olarak Beslenme Risk İndeksi (NSI) kullanılmıştır. Bu çalışmada 51 demanslı bireyin; 21'inde orta risk malnütrisyon, 17'sinde yüksek risk malnütrisyon tespit edilmiştir. Çalışmamızda literatürle paralel olarak demans hastalığ $\breve{1}_{1}$ ile malnütrisyon değeri arasında istatistiksel olarak anlamlı bir farklılığın olduğu belirlenmiştir $(p=0,001)$.

Yaşlılık ve yaşlılığın getirdiği hastalıklar ile bilişsel fonksiyonlarda azalma görülmektedir. Bilişsel fonksiyonlardaki bu azalma günlük yaşam aktivitelerini etkilemekte ve yaşam kalitesini azaltmaktadır. Nörolojik hastalıkları olan yaşlı bireylerin diğer yaşlılara göre GYA'da bağımlılık derecelerinin arttığı literatürdeki diğer çalışmalarla da desteklenmektedir. ${ }^{27}$ Bizim çalışmamızda Katz Günlük Yaşam Aktiviteleri Ölçeği ile demans arasında istatistiksel olarak anlamlı bir farklılığın olduğu belirlenmiştir $(p=0,000)$. Lawton\&Brody Enstrümental Günlük Yaşam Aktiviteleri Ölçeği ile demans arasında da istatistiksel olarak anlamlı bir farklılık vardır $(p=0,000)$. Literatürle benzer şekilde demans tanısı almayan bireylerin ölçek puanları daha yüksektir. Günlük yaşam aktivitelerinin değerlendirilmesi demansta kritik bir yol gösterici olabilir. ${ }^{28,29}$ Fonksiyonel defisitlerin şiddeti birçok çalışmada demans hastalarındaki mortaliteyle ilişkili bulunmuştur. $\mathrm{Bu}$ nedenle günlük yaşam aktivitelerinin değerlendirilmesi demans tanısının spesifite ve sensitivitesini artırabilir, bireylerin bakım ve beslenme gereksinimleri açısından önemlidir.

El kavrama gücü, fiziksel performansın yorumlanması için iyi bir değerlendirme aracıdır. Düşük el kavrama gücü, bilişsel gerileme ve demans riski ile bağlantılı olduğu düşünülmektedir. Hatabe ve ark, 24 yıl süren izlem çalışmasının sonucunda el kavrama gücündeki düşüş demans riski arışı ile ilişkilendirilmiştir. ${ }^{30}$ Ancak literatürün tersine bizim çalışmamızda el kavrama gücünün demans hastalığına göre istatistiksel olarak anlamlı bir farklılığın olmadığ belirlenmiştir $(p>0,05)$. Lier 
ve Payette yaptıkları bir çalışmada malnütrisyon ve el kavrama gücü ilişkisini araştırmıştır ve çalışmanın sonucunda yaşla birlikte artan malnütrisyonun el kavrama gücünde düşüş ile ilişkili olduğu bulunmuştur. ${ }^{31} \mathrm{Bu}$ çalışmada da literatür ile paralel olarak malnütrisyon ve el kavrama gücü arasında istatistiksel olarak anlamlı bir fark bulunmuştur $(\mathrm{p}=0,000)$.

Demanslı hasta sayısı ülkemizde ve dünyada her geçen gün artmaktadır. Bu nedenle demansta beslenme sorunlarının bilinmesi, önlenmesi ve tedavi edilmesi önem kazanmaktadır. Tanı konulan her demans hastasının malnutrisyona aday olduğu unutulmamalı ve malnütrisyonun engellenmesi ve fonksiyonel bağımsızlığın sürdürülebilmesi için hastanın yeterli ve dengeli beslenmesi sağlanmalıdır. Hastalarda yeterli kalorili ve proteinden zengin beslenmeye önem verilmelidir. Beslenmenin demansa olan etkilerinin incelenmesi için daha fazla çalışma yapılması demanslı bireylerin tıbbi beslenme tedavisine fayda sağlayacaktır.

\section{Çıkar Çatışması}

Yazarların, makaleleriyle ilgili çıkar çatışmaları yoktur. Makalede dolaylı veya dolaysız ticari bağlantı (istihdam edilme, doğrudan ödemeler, hisse senedine sahip olma, firma danışmanlığ 1 , patent lisans ayarlamaları veya hizmet bedeli gibi) veya çalışma için maddi destek veren kurum mevcut değildir.

\section{KAYNAKLAR}

1. United Nations, Department of Economic and Social Affairs, Highlights (2017). World Population Ageing 2015;p1 (ST/ESA/SER.A/397).

2. Yaşlı nüfus sayımı, Türkiye İstatistik Kurumu verileri, 2019. Erişim adresi: http://www.tuik.gov.tr/PreHaberBultenleri. do? id=24644. Erişim tarihi: 06.02.2021

3. Greenwood CE, Parrott MD. Nutrition as a component of dementia risk reduction strategies. Healthc Manag Forum 2017 Jan;30(1):40-45.

doi: $10.1177 / 0840470416662885$.

4. Cunningham EL, McGuinness B, Herron B. Dementia. Ulster Med J 2015 May;84(2):7987.

5. Emre M. Classification and diagnosis of dementia: A mechanism-based approach. Eur J Neurol 2009 Feb;16(2):168-73. doi: 10.1111/j.1468-1331.2008.02379.x

6. Livingston G, Sommerlad A, Orgeta V, Costafreda SG, Huntley J, Ames D, et al.
Dementia prevention, intervention, and care.Lancet 2017 Dec;16;390(10113):26732734. doi: 10.1016/S0140-6736(17)31363-6.

7. Volkert D, Chourdakis M, Faxen-Irving G, Frühwald $\mathrm{T}$, Landi $\mathrm{F}$, Suominen $\mathrm{MH}$, et al. ESPEN guidelines on nutrition in dementia. Clin Nutr2015Dec;34(6):1052-73. doi: 10.1016/j.clnu.2015.09.004.

8. 8. Franx BAA, Arnoldussen IAC, Kiliaan AJ, Gustafson DR. Weight loss in patients with dementia: considering the potential impact of pharmacotherapy. Drugs Aging. 2017;34(6):425-36.

9. Chen JH, Lin KP, Chen YC. Risk factors for dementia. JFormos MedAssoc 2009 Oct;108(10):754-64. doi: 10.1016/S09296646(09)60402-2.

10. Bendich A. Fundamentals of nutrition and geriatric syndromes. In: Bales $\mathrm{CW}$, Ritchie CS, Wellman NS, editor. Handbook of Clinical Nutrition and Aging. 2th ed. New York: Humana Press; 2009.p.65-235.

11. Özgüneş N. Huzurevinde yaşayan yaşlılarda beslenme durumunun taranmasi: Tarama testleri kıyaslamasi. Hacettepe Üniversitesi Sağllk Bilimleri Enstitüsü Beslenme Bilimleri Programı Yüksek Lisans Tezi, Ankara, 2013.

12. Katz S, Ford AB, Moskowitz RW, et al. Studies of illness in the aged. The index of adl: A standardized measure of biological and psychosocial function. JAMA. 1963;185:914919

13. Arık G, Varan HD, Yavuz BB, et al. Validation of Katz index of indepence in activities of daily living in Turkish older adults. Arch Gerantol Geriatr 2015; 61;344-350.

14. Lawton MP, Brody EM. Assessment of older people: self-maintaining and instrumental activities of daily living. Gerontologist. 1969; 9(3):179-186.

15. Şahin S, Boyacıoğlu H, Taşar P.T, Kozan E, Sarıkaya O.F, Akçiçek F, Bornova ilçesinde yaşayan 65 yaş üzeri nüfustaki fonksiyonel bağımlılık oranları, Ege Tip Dergisi 2016;55(2):65-70

16. Güzel A, Üner S, Turan S, Uçan Yamaç S.Lawton ve Brody Enstrümental Günlük Yaşam Aktiviteleri Ölçeği Türkçe Geçerlik ve Güvenilirliği. 3. Uluslararası 21. Ulusal Halk Sağlığ1 Kongresi, Antalya. 2019;s733

17. Garner DM, Bohr Y, Garfinkel PE. The eating attitudes test: psychometric features and clinical correlates. Psychol Med 1982 Nov;12(4):871-8. doi: 10.1017/s0033291700049163.14.

18. Ergüney-Okumuş FE, Sertel-Berk HO. Yeme Tutum Testi k1sa formunun (YTT-26) Üniversite örnekleminde Türkçeye uyarlanması ve psikometrik özelliklerinin değerlendirilmesi. 
Psikoloji Çalışmaları. 2020;40(1):57-78. https://doi.org/10.26650/SP2019-0039

19. Behrens S, Wengreen H, Lyketsos C, Sanders C, Tschanz J, Schwartz S. Nutritional status and severe dementia, institutionalization, and mortality: The cache county dementia progression study. Alzheimer's Dement. 2015;11(7):p835.

20. López-Pousa S, Vilalta-Franch J, Llinàs-Regla $\mathrm{J}$, Garre-Olmo J, Román GC. Incidence of dementia in a rural community in Spain: The Girona cohort study. Neuroepidemiology. Neuroepidemiology 2004;23:170-177

21. Galesi LF, Leandro-Merhi VA, de Oliveira MRM. Association between indicators of dementia and nutritional status in institutionalised older people. Int $\mathrm{J}$ Older People Nurs 2013 Sep;8(3):236-43. doi: 10.1111/j.1748-3743.2012.00321.x.

22. Gorzoni ML, Pires SL. Aspectos clínicos da demência senil em instituições asilares Clinical aspectcs of the senile dementia in long-term care facilities. Rev Psiq Clin 2006;33(11):1823.

23. Walker JG, Batterham PJ, Mackinnon AJ, Jorm AF, Hickie I, Fenech M. Oral folic acid and vitamin B-12 supplementation to prevent cognitive decline in community-dwelling older adults with depressive symptoms - The Beyond Ageing Project: A randomized controlled trial. Am J Clin Nutr 2012 Jan;95(1):194-203.

24. Ford AH, Flicker L, Alfonso H, Thomas J, Clarnette R, Martins R. Vitamins B12, B6, and folic acid for cognition in older men. Neurology. 2010 Oct 26;75(17):1540-7.

25. Sanders C, Behrens S, Schwartz S, Wengreen $\mathrm{H}$, Corcoran CD, Lyketsos CG. Nutritional
Status is Associated with Faster Cognitive Decline and Worse Functional Impairment in the Progression of Dementia: The Cache County Dementia Progression Study. J Alzheimer's Dis 2016;Feb 27; 52(1): 33-42.

26. Meyer S, Gräske J, Worch A, Wolf-Ostermann K. Nutritional status of care-dependent people with dementia in shared-housing arrangements - a one-year follow-up. Scand J Caring Sci 2015 Dec;29(4):785-92. doi: $10.1111 /$ scs. 12210 .

27. Camcı Y. Demans tanılı yaşlıların günlük yaşam aktiviteleri ile MMSE skorları arasındaki ilişki. Akad Geriatri. 2010;2:52-53.

28. Desai AK, Grossberg GT, Sheth DN. Activities of daily living in patients with dementia: clinical relevance, methods of assessment and effects of treatment. CNS Drugs. 2004;18:853785.

29. Bachman DL, Wolf PA, Linn RT, Knoefel JE, Cobb JL, Belanger AJ, et al. Incidence of dementia and probable Alzheimer's disease in a general population: the Framingham Study. Neurology. 1993;43:515-519.

30. Hata J, Yoshida D, Hatabe Y, Oishi E, Honda $\mathrm{T}$, Shibata M. Decline in handgrip strength from midlife to late-life is associated with dementia in a Japanese community: the Hisayama Study. J Epidemiol 2020; 30(1): 1523.

31. Van Lier AM, Payette H. Determinants of handgrip strength in free-living elderly at risk of malnutrition. Disabil Rehabil. 2003 Oct 21;25(20):1181-6. doi: 